\title{
Sydney's SoHo Syndrome? Loft living in the urbane city
}

\author{
Wendy S. Shaw
}

School of Biological, Earth and Environmental Sciences, University of New South Wales

\begin{abstract}
In its ongoing search for a global identity, the city of Sydney, Australia, has looked to other cities for inspiration and direction. Like many of these cities, Sydney's Central Business District, and the former industrial areas that surround it, are being transformed through 'apartment' (condominium) development. Many are marketed as 'New York-style lofts' via a flurry of promotions that suggest a distinctly generic and global form of cosmopolitan urbanism. The essay details how this recent spate of Manhattanization rests not only on a cache of historically embedded Manhattan imaginaries, but on localized socio-cultural moments that are part of Sydney's particular experience of SoHo Syndrome. Tracing the pathways to Sydney's version of the global phenomenon of loft living has enabled a deeper understanding of the city's evolving built and cultural landscapes.
\end{abstract}

\section{Introduction}

To appropriate is to take control over that which originated elsewhere for other semiotic/ideological purposes. $^{1}$

The first application to convert an old warehouse into apartments ${ }^{2}$ in the centre of

Sydney, Australia, was lodged in 1979 and marked a turning point in the city's history. Apartment/condominium development has become a major force in reshaping the urban fabric of many cities around the world, ${ }^{3}$ and in Australian inner cities, former industrial and commercial landscapes are being reborn as housing. Setting the trend in Australia, the apartment boom at the centre of the city of Sydney has facilitated a fundamental and deliberate cultural shift. Before suburbanization, after the Second World War Sydneysiders mainly inhabited inner-city terraced (row) houses, just outside the Central Business District (CBD) (Figure 1). With suburbanization, and prior to recent gentrification, most people lived in suburban bungalows. With the march of gentrification during the 1970s and 1980s, and the restoration of Victorian houses that dominated the inner city, artists and musicians also occupied inner-city warehouses and empty CBD buildings, as studios and for cheap housing. However, such occupations were generally based on informal arrangements, until a stage of wholesale commodification and the advent of 'apartments', in the late 1990s. As gentrification cycles matured, ${ }^{4}$ and existing housing and land stocks escalated in price, ${ }^{5}$ apartment development began with the conversion of old warehouses. This heralded a dramatic 


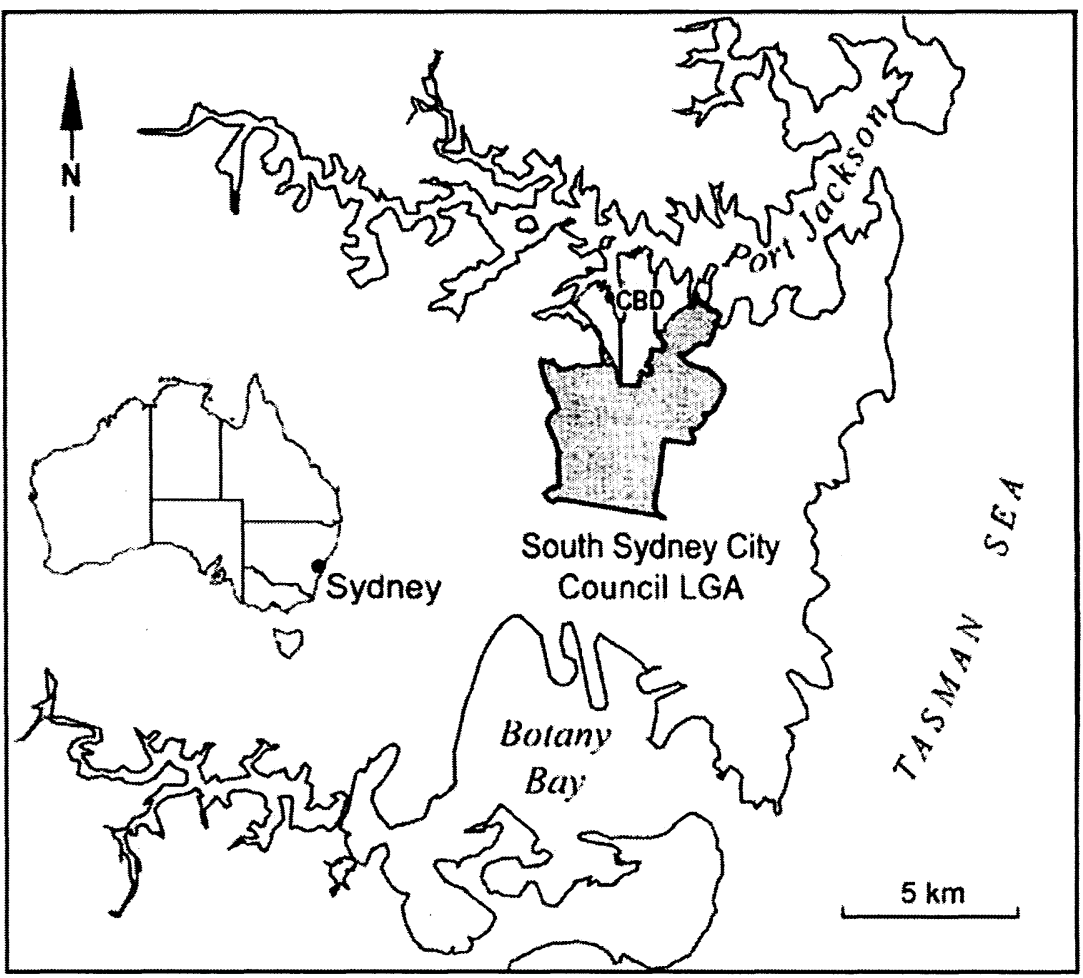

FIGURE 1 Sydney's Central Business District and (former) South Sydney City Council Local Government Area

departure from the usual taste cartographies for Australian housing. To sell the hitherto suburban nightmare - the earlier versions of apartments were dubbed 'flats' or 'home units' - required complete reinvention. The result is that apartment living in Australian cities is now widely associated with urbanity and global cosmopolitanism. The advent of Sydney's own version(s) of that now highly recognizable global trend, referencing the Manhattan phenomenon of loft living, ${ }^{6}$ signified this large-scale reorientation.

The redevelopment of inner cities is about more than the material rebuilding of depleted areas, and processes of urban reimaging have been well documented. ${ }^{7}$ Considerations of developer-driven urban transformations ${ }^{8}$ now include detailed accounts of the change in lifestyles that accompany large-scale residential redevelopment. ${ }^{9}$ New urban lifestyles are well-recognized components of the cultural capitals of transforming neighbourhoods, ${ }^{10}$ where linkages occur between inner-city transformations, global capital formations and place-specific identity traits. ${ }^{11}$ However, to avoid proliferating what David Ley ${ }^{12}$ recently identified as 'globe talk' - a 'master discourse reproduced in intellectual, policy and corporate circles' that privileges economistic explanations for urban processes - this essay seeks to engage with contemporary understandings of 'urbanism'. ${ }^{13}$ Urbanism is defined generally as: 
the social and behavioural characteristics of urban living which are being extended across society as a whole as people adopt urban values, expectations and lifestyles. ${ }^{14}$

Identifying urbanism in this way 'opens out'15 a prevailing assumption that the ways people live in cities 'merely reflect[s] the social organization of a particular economic order: capitalist urbanism [which is] ... fundamentally different to socialist urbanism'. ${ }^{16}$ This shift, and engagement with localized behaviours, has assisted in unsettling the 'classical modernist vision' of the industrial metropolis. ${ }^{17}$

This essay presents a set of stories that reflect the complexity of sociocultural and economic processes that have enabled the city of Sydney to host its own version of 'New York style' loft living. ${ }^{18}$ These stories detail cultural attributes, acknowledged and otherwise, that are associated with the production and consumption of this new field of housing, in Australia. They detail the processes that have embedded an increasingly generalized form of metropolitan urbanity that pretends to hark from elsewhere. Within this complexity are moments that are, I believe, unsung contributors to the cultures, and therefore cultural capitals, ${ }^{19}$ of loft living, or what Julie Podmore ${ }^{20}$ identified as 'SoHo Syndrome', in Sydney, Australia. In her account of the emergence of 'New Yorkstyle' loft apartments elsewhere, and specifically in Montreal, Canada, Podmore defined SoHo Syndrome ${ }^{21}$ as:

a spatial and cultural process that involves more than simply copying the aesthetic of SoHo [New York] as a redevelopment strategy ... cities are 'locales' ... [and SoHo Syndrome is] more than a universal valorization strategy: it is a socio-cultural process that involves a complex web of relationships between place, identity and the media, that is diffused to, and (re)produced in, divergent inner-city locations. ${ }^{22}$

In line with recent gentrification research, Podmore ${ }^{23}$ reiterated a tendency to focus on the consumption rather than the production of loft landscapes. ${ }^{24}$ Through her case study, she demonstrated that a serious interrogation of loft (re)production requires more than just a reading of consumption, and associated loft lifestyles. After tracing some of Sydney's earlier Manhattanization-moments, I seek to demonstrate how, once embedded, the associated and now highly fetishized housing form of New York-style loft apartments celebrates more than the consumption of a somewhat amusing marketing rhetoric. On closer inspection, loft promotions have provided a formula for new forms of urbanism that include cultures of escapism, or remoteness, from the local and its histories.

The great urbanist Georg Simmel ${ }^{25}$ once posited that denial of the everyday, which can become indifference in a more advanced state of dislocation, activates a sense of remoteness. Extrapolating from this idea, the local, including the politics and struggles of the past and the present, can be temporally and spatially disconnected. In earlier work, ${ }^{26}$ I contemplated the processes of temporal selectivity, engagement (and disengagement) with specific pasts, using examples of resident activism in the protection of (white, colonial) heritage in inner Sydney. In these cases, the protection of select pasts enabled an escape from unpleasantness in the present. ${ }^{27}$ With the preservation of industrial façades, which romanticize specific aspects of the past such as the owner or purpose of the building, the often horrendous workplace conditions from within are stripped out. ${ }^{28}$ Sydney's version of loft living similarly promises minimal 
engagement with the local and its histories, through design. As detailed later, the marketing devices used to sell Sydney's lofts invoke a metropolitan fantasy of a cosmopolitan, and globally generic, urbanity.

Dazzling portrayals of 'New York, New York' have been used to reimage and promote the sale of Sydney's former industrial and commercial inner-city areas as domestic spaces. I contend, however, that such reimaging is different from a mere reproduction of the New York experience, which did acknowledge earlier, more bohemian warehouse/loft occupations. ${ }^{29}$ Almost irreverently, the Sydney experience has traded on fantasies of Manhattan/New York through icons such as images of Gotham, Sinatra's famous song, references to 'Broadway' and the use of gentrifying district names such as Tribeca, as well as the use of specific building names, such as 'Dakota' (see Figure 2). And just as imaginaries of escape from the here and now are produced by drawing on images of romanticized and exclusive pasts, ${ }^{30}$ imagining elsewhere, as SoHo Syndromes surely must, produces escape and diversion. In what follows, I will argue that the Sydney version envisions new forms of exclusionary urbanism. ${ }^{31}$ As Parekh has observed, 'cosmopolitan liberal political philosophy, [which dominates conceptions of urban renewal] though inspiring in its universal ambitions [such as the development of recognizable housing forms], marginalizes other positions'. 32

In an earlier discussion, I considered racialization in gentrifying city spaces through Sydney's identification with (an imagined white) Manhattan and the coincident 'Harlemization' of an incumbent city-based Indigenous community, in Redfern. ${ }^{33}$ This essay unpacks specific and exclusionary discursive strategies used in the restructuring of metropolitan Sydney life. Although ignored in the recent and current marketing discourses, which are summarized here from an archive of reimaging from 1997 to 2000, I have pieced together remnants of Sydney's own encounter with residential occupation of old commercial and industrial buildings. These fragments, of collective imaginations, memories ${ }^{34}$ and memorabilia, have exposed various 'cultural encodings' ${ }^{35}$ And although these artefacts of Sydney's evolving Manhattanism ${ }^{36}$ have not disappeared, they have remained largely unnoticed, and disengaged from the current ultra-commodified phase. Using a mixed-methods format, ${ }^{37}$ I have (re)told some of these 'hidden' histories that lie beneath a rapidly changing urban landscape. The lack of formal records on warehouse living meant delving into less than conventional data sources, including my own recollections - my experiences of warehouse cultures in the late 1970s and 1980s. This led to conversations with (other) warehouse 'survivors' who provided anecdotal moments, and provided stimulus, for accessing other avenues. Snippets of details were also found in local newspapers and newsletters, fringe/alternative publications, a CD-ROM (detailed later) and several websites. $^{38}$ These remnants were woven together to provide a sketch of this history. Such histories do not exist in isolation. The stories of Sydney's evolving housing landscapes, discussed in this essay, have been contextualized with details about changing urban property values, and about market shifts - from commercial to residential - over the past few decades, and the associated demographic changes. ${ }^{39}$ Within this socioeconomic context, I have drawn together the narratives that dominated 


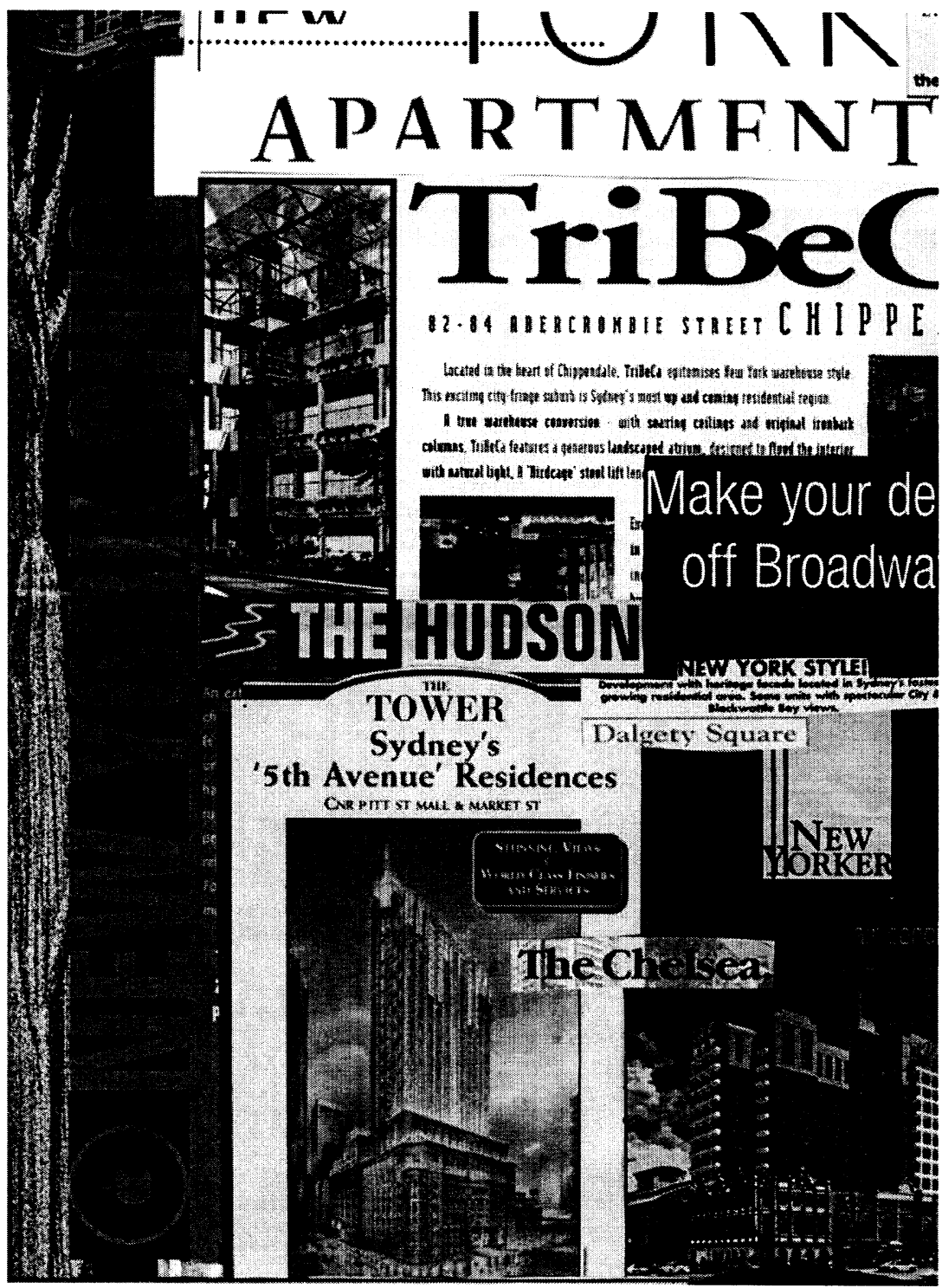

FIGURE 2 Collage of advertisements for Sydney's loft living

the marketing discourses used to promote (loft) apartments during the redevelopment explosion in inner Sydney, in the late 1990s. ${ }^{40}$ Media commentaries and the narratives of stakeholders, such as real estate agents, also provided a rich vein of discursive data in the production of a reimaged urbane city. Thirty-five semi structured (in-depth) interviews, with residents and business people living under the shadows of loft conversions in 1997 and 1998, ${ }^{41}$ also contributed detail about the fears and expectations of such dramatic urban redevelopment. In 2001, another 30 in-depth interviews, with 
new apartment dwellers, contributed an invaluable layer of individual experiences of loft living to the analysis of the consumption of lofts in Sydney. ${ }^{42}$

\section{From 'warehouse' to 'loft' living}

When Sharon Zukin's 'Loft living' appeared in 1982, the inner city of Sydney was experiencing its own determined, but hitherto undocumented, residential occupation of former industrial and commercial buildings. Low-income earners, such as students, artists and musicians, had sought 'creative' refuge from suburbia and conventional inner-city housing (terraces and old flats) through the occupation of warehouses and unused office buildings. The city beckoned those who preferred the social interaction afforded by living amongst 'like-minded' city people. Universities, colleges, diverse lifestyles and nightlife were all located close together. Some, oppressed by suburban life, ${ }^{43}$ found greater freedom in the inner city. For some, the move from a conventional suburban house to a spacious but shabby warehouse/office building soon became desirable urban chic. An oversupply of city buildings provided a vein of alternative accommodation throughout the 1970s and 1980s. Global economic trends combined with sociocultural shifts to produce a quite lengthy moment of low-income accommodation within which bohemian lifestyles could flourish. Although not part of the recent spate of apartment promotions, warehouse occupations did help to preserve many buildings that now carry the 'loft' tag. More significantly, they promoted an appreciation of industrial chic in Sydney.

The advent of the formal conversion of warehouses into apartments in Sydney's CBD also began in the late 1970s. According to John Roseth, ${ }^{44}$ head researcher at the former New South Wales ${ }^{45}$ Department of Environment and Planning, who reported on a new trend in 'recycling old buildings' in inner Sydney (in 1981), approximately 77 sites were approved for conversion between 1979 and 1981. Horvath and Engles noted that the 'conversion of warehouses and light manufacturing structures into 'loft-style' residences ... appeared in Sydney in at least the early 1980s'. ${ }^{46}$ Formal conversion would provide a way to use unwanted buildings, but was a strategy that required outlays of large sums of capital at a time of low market demand. Meanwhile, a cheap residential alternative was available for those who wanted to rent otherwise unused buildings as 'studio spaces'.

\section{Emerging (spaces for) warehouse cultures}

Unconventional residential accommodation probably started in inner Sydney just after the Second World War, when residential accommodation was in short supply. From the late 1940s, the CBD had become home to the Sydney Libertarians (later known as 'the Sydney Push'). This 'notorious group of anarchic intellectuals' ${ }^{47}$ deliberately shunned conventional suburban living arrangements, preferring low-rent 
boarding houses, run-down terrace houses, pubs and otherwise decreasingly 'desirable' forms of accommodation. By the late 1970s, warehouse living had become an established lifestyle alternative for those involved in the inner-city art/ music scene. Landlords leased empty office and warehouse buildings all over the inner city and $\mathrm{CBD}$, for residential purposes. Because living in a warehouse or office building was 'illegal', as commercial or industrial zoning made no provision for habitation, the formal conversion process was slow. Most warehouse sites occupied business or industrial, rather than residential zones. ${ }^{48}$ At a time of high vacancy rates in the 1970 s and 1980s, however, the 'illegality' of residential occupation of warehouses and old office buildings was of secondary importance to much needed rental returns.

Roseth noted that 'Sydney had a boom in office buildings in the early 1970s ... [that] ... left the owners of the old office buildings with few options of how to keep their properties economically productive ${ }^{49}$ The city was also experiencing widespread office and warehouse abandonment, which culminated in an office glut in the late $1980 \mathrm{~s} .{ }^{50}$ Firms and industries were decentralizing, moving out of the inner-city areas to cheaper locations on the city fringes ${ }^{51}$ or moving 'offshore'. Some simply succumbed to larger global economic shifts at the time, with many industries, such as the local clothing and footwear manufacturers, losing business because of cheaper imports from the 'Newly Industrialized Countries' of Latin America and Asia. ${ }^{52}$ These economic shifts, and the associated rise in availability of commercial properties in the inner city, enabled a variety of uses for large, increasingly unoccupied buildings, until the enforcement of usage regulations occurred with another turn in economic fortunes in the 1990s.

Roseth $^{53}$ attempted several forecasts about the development of warehouse apartments but did not predict the displacement of low-income residents. He argued that because the conversion of existing buildings was cheaper than redevelopment, the saving would stimulate lower-cost purchasing power in the inner city. This somewhat naive forecast was accompanied by the statement: 'Beyond these [economic] reasons, there hovers that rather nebulous motive - what society considers chic or fashionable - which does not always spring from compelling logic, but which seems to exercise a compelling force on behaviour. ${ }^{54}$ Along with these seemingly illogical cultural considerations, Roseth did not completely ignore the political economy of gentrification either: 'Certainly history has shown that when a residential area suddenly becomes desirable, the wealthy tend to displace the poor who used to live there. ${ }^{55}$ He qualified this with:

Residential development in the Central Business District cannot be seen in the same terms as the resurgence of those inner suburbs ... The Central Business District has been without a residential population; there is no question of displacing low-income residents ... buildings proposed for recycling are usually those which have stood empty or balf-occupied for some years. ${ }^{56}$

Two points about these 'half-occupations' should be made. First, although economic forces may be oblivious to the fate of people living in the margins and interstices of (mainstream) societal norms, the contradictions of 'free market forces' actually 
provided the moment for alternative housing opportunities in Sydney at the time. The culture of warehouse chic emerged to fill in the gaps of the economies of CBD and inner-city commercial property ownership. These gaps closed when the time was economically 'right' for warehouse living to undergo mass commodification and become Sydney's version of loft living.

The second point about the 'half-occupations' is that the informal or 'illegal' sector of warehouse occupation was largely officially 'invisible'. Certainly, commercial or industrial leases did not record residential occupations, but it is the ambiguous halfoccupations that Roseth noticed that suggests the displaced residential occupiers. Along with occupations, displacements from warehouses were also unnoticed in official terms. Despite this lack of official recognition, warehouse and loft occupations in Sydney (and other parts of the world ${ }^{57}$ ) were noticed by those who were there, who experienced or witnessed this phenomenon, including its demise. Remembrances of the Sydney experience, and its entrenchment within the cultural foundation of a city, are discussed below.

\section{Remembering warehouse cultures}

The use of warehouses and office buildings for residential purposes was very different from the predominantly suburban lifestyles in Sydney at that time. Anyone who has lived in the inner city since the halcyon days of warehouse occupations would remember various warehouse communities. Some warehouses gained folkloric status. ${ }^{58}$ Others were simply notorious. ${ }^{59}$

Examples of residential warehouse occupations included various buildings along the Southern end of Pitt Street in Sydney's CBD. Some of the larger warehouses hosted huge dance parties during the 1980s, which were the precursors to the commercial dance scene, such as the internationally acclaimed Lesbian and Gay Mardi Gras (postparade) party, held annually. An old department store, the Anthony Horderns building, sat on a site now occupied by the multi-purpose commercial and residential conglomeration called World Square, in the CBD, and was home to artists and musicians from the late 1970s to the mid-1980s. The enormous, now demolished, Xerox building (Alexandria/Zetland, just south of the CBD) similarly housed (fringe) artists and musicians, as did various smaller buildings dotted around Darlinghurst/East Sydney and Surry Hills, which were all within a few kilometres of the CBD. Some warehouse conversions resulted in the eviction of long-term warehouse communities. These included the Spice Traders building in Surry Hills, which was converted in $1995,{ }^{60}$ and the Shepherd and Newman Printery in East Sydney, which became luxury lofts in 1997. One of the longest-ranging occupations, the Silknit Building ${ }^{61}$ in Surry Hills, was converted in 2000.

Although many buildings earmarked for redevelopment were demolished or partially demolished, artefacts of these cultural moments remain as objects, and memories. An example is the now demolished Slaughterhouse (former abattoir and meat-packing building) in Redfern, which is one train stop south of the CBD. The 
Slaughterhouse was a huge, constantly evolving multi-purpose concern with recording and practice studios for musicians, artist lofts, art galleries and separate 'living spaces'. This unofficial occupation lasted for well over a decade and left art objects and recordings, as well as the memories of cheap practice and recording studios for musicians. $^{62}$

Other examples of residentially occupied warehouses with notable warehouse cultures included Alpha House, and the former Beta House in Newtown, south of the CBD. A property developer converted Beta House into 29 'loft apartments' and sold them off at 'luxury' prices in the mid-1990s. This prospect was not without contest, and the former occupants of Alpha and Beta Houses, and other locals, objected to development proposals for the two sites. The 30 letters received by the local council opposed the loss of a viable art and music community. ${ }^{63}$ The larger and more imposing building of the two, Alpha House, formerly home to a thriving rent-paying and at times infamous party-throwing community, sat empty and gutted throughout the 1990s. The developer, Robmet Investments Pty. Ltd., submitted a Development Application in 1993, ready for the impending boom in 'loft' developments, but the conversion stalled. ${ }^{64}$ Alpha House sat empty for many years as a testimony to developer speculation and, perhaps less obviously, to former informal occupancy. ${ }^{65} \mathrm{~A}$ CD-ROM publication ${ }^{66}$ immortalized its former life, as did a Sydney newspaper in an article titled 'Home is where the art is'. ${ }^{67}$ After it ran its story on the 'former glory' of Alpha House, a rash of callers - those who had lived there or knew about it and wanted to know more - telephoned a local independent newspaper, the Newtown Times. ${ }^{68}$ This kind of inner-urban 'underground' culture is remembered by some, and at times the nostalgia for this largely bygone era is rehearsed. As a resident of a terraced house in Darlington noted, evoking a familiar lament about the loss of cheap city 'spaces':

There was light industry then it became a lot more artistic in usage. Those sorts of people ... need large warehouse spaces close to the city ... they're getting squeezed out, there's nowhere for them to go, and so a whole artistic community in Sydney is just being pushed out. Where are they going to end up? I mean we've really got the death throes on a lot of artists here. ${ }^{69}$

Although there were several survivors, the cheap rental alternative came to a virtual halt with a sudden increase in real estate prices from the mid- to late 1980s. During that time, local governments deployed policies to encourage building 'recycling':

Ordinance 70 allows councils full discretion regarding the extent to which the requirements it would make of a new building are applied to the alteration of an old one ... one [economically productive option was] to convert [old 'unproductive' buildings] to residential. ${ }^{70}$

Consequently, existing warehouses and old office buildings attracted developers and loft conversions began - haltingly, as an economic recession interrupted the processes for several years. ${ }^{71}$ The Mansions in Surry Hills, adjacent to the CBD, was a conversion that stalled in the early 1990s and was then completed in late 1998 (similar to Alpha House). Many developers sat out the recession, as did many old buildings until the late 1990s, when Sydney's loft landscapes mushroomed. 


\section{Sydney's SoHo Syndrome}

The Manhattanization of Sydney proceeds apace.... As the central city ... becomes more affluent ... linkages between global cities - Sydney and New York - begin to rival linkages between nation states. $^{72}$

Apart from such bombastic journalistic claims, visual and other references to Manhattan/New York increased around the city of Sydney in the lead up to the 2000 Olympic Games. Whether parodying or revering the hype, a lone street performer provided Circular Quay, at the harbour foreshores of the CBD, with its own modest Statue of Liberty for several months. ${ }^{73}$ A much grander visual extravaganza arrived in 1998 with the launch of a series of airline advertisements. Perched on three of the most prominent billboards in the city, the advertisements caught the attention of Sydney's main road users. One dominated the southern exit from the Sydney Harbour Bridge, capturing the attention of southbound and westbound traffic. The second loomed over Taylor Square, a major arterial road junction for vehicles travelling east and south. The third looked down on Broadway (yes, Broadway) to catch the attention of those traveling out of the CBD to the west and south-west. The advertisements featured an enormous image of the Statue of Liberty. The sails of the Sydney Opera House replaced the usual flames atop the statue's torch. The image cleverly melded two cities: New York and Sydney.

At first glance, the advertisement appeared to be a marriage of the bigger, older city (New York) and the smaller, showpiece city (Sydney). A famous New York icon (Statue of Liberty) held a famous Sydney icon (Sydney Opera House). The quick and simple message was the unification of New York and Sydney by an airline, but the more sinister reading is that the 'big sister' city appeared to be incinerating the 'littleshowpiece' with her torch. Regardless of the various interpretations, the Sydney-based advertising company used by the airline linked Sydney and New York to appeal to consumers of airline tickets. Away from freeway advertising, real estate promoters were promising to bring New York to Sydney, or even to turn Sydney into a quasi-Manhattan (and metaphorically ignite Sydney with that flaming torch).

\section{Promoting loft living in Sydney}

In a 2001 newspaper article, the president of the Royal Australian Institute of Architects, Graham Jahn, identified two distinct stages in Sydney's apartment culture: 'the first was in the 1920s to 1940 s period, which was based on a New York-style apartment ... [and the second is] a more sophisticated range of developments providing an alternative to living in ... houses. ${ }^{74}$

An editorial in a local inner-city newspaper ${ }^{75}$ conjectured that the first Manhattan/ New York themed apartment development was the Central Park ${ }^{76}$ in Surry Hills, which was a warehouse converted into "70 "loft-style" apartments" in September 1997. There was, however, an earlier 'loft conversion', the Lacey (see Table 1 for list of loft developments and advertising focal points ${ }^{78}$ ). Promoted in February 1997, this 
development marked a notable change in real-estate promotion technologies. A striking banner, slung from the top of the existing unrenovated building in Redfern, resembled the enormous advertisements on the sides of buildings in Times Square, or along Broadway in Manhattan. To assure prospective buyers that the stigmatized area would not be problematic, a promotional priority - which became an advertising precedent - was the mention of hi-tech security measures. ${ }^{79}$ The accompanying brochure also promised prospective buyers that the Lacey was 'Sydney's hot spot of growing value' in an area that might be the next Paddington, ${ }^{80}$ which is just to the east of the CBD. Buying into the loft market was touted as smart and secure investment in gentrification.

Soon after Lacey, direct Manhattan/New York referencing began throughout the inner city of Sydney, with a spate of developments with distinctly New York names. One of the first apartment buildings to carry a New York name was the somewhat too obvious Manhattan. The Sydney Morning Herald (SMH) carried advertisements for the Manhattan from April 1997, which included a striking and shadowy image of the Statue of Liberty.

An onslaught of promotions followed, including the Madison ${ }^{81}$ (referencing Madison Square Gardens in Manhattan), which promised a 'Manhattan lifestyle' in the former industrial area of Chippendale, located between Redfern and the CBD. Accompanying the image of the development, with its faint echoes of the design of the Manhattan original, the advertisement for the Dakota ${ }^{82}$ stated that 'the new Manhattan style Dakota apartments offer the vibrance and excitement of the city ... video/intercom security and parking/highspeed lifts'. This Sydney version of the famous Manhattan residential building offered a formula for a dynamic Manhattan-style apartment, complete with hitech security.

Dakota is one of the many developments built by Meriton Pty Ltd., one of the largest Sydney-based property-development corporations. Meriton followed Dakota with the release of Paragon, Paramount, Palladium and Dalgety Square, ${ }^{83}$ and used explicit Manhattan referencing in the promotional materials. In April/May 1997, Meriton began its prominent full-page advertising in the main real-estate promotional medium, the SMH's Saturday Real Estate section (now dubbed Domain). Manhattan-referenced themes included stepped rooflines and two-tone colours that echoed architectural styles of the 1920s and 1930s. From this point onwards, promotions by other developers, large and small, followed the Manhattan theme. For example, Powerhouse Apartments offered 'Elegant living, New York Style', and the Lincoln ${ }^{84}$ promoted 'New York style Apartments' ('Lincoln' referenced the famous Lincoln Center, a major Manhattan landmark). More recently, Union Square ${ }^{85}$ was advertised as 'an absolutely authentic warehouse conversion in grand style! ... The latest expression of loft living New York style in the vibrancy of Sydney.'

Taking the Manhattan theme to a new level in promoting Sydney loft apartments, TriBeCa claimed to be 'Warehouse Living that exceeds your expectations ... TriBeCa epitomizes New York warehouse style... a birdcage steel lift ... unrestricted skyline.' The promoters were well aware of the connotations of naming the development after a Manhattan neighbourhood that was also in the throes of loft 


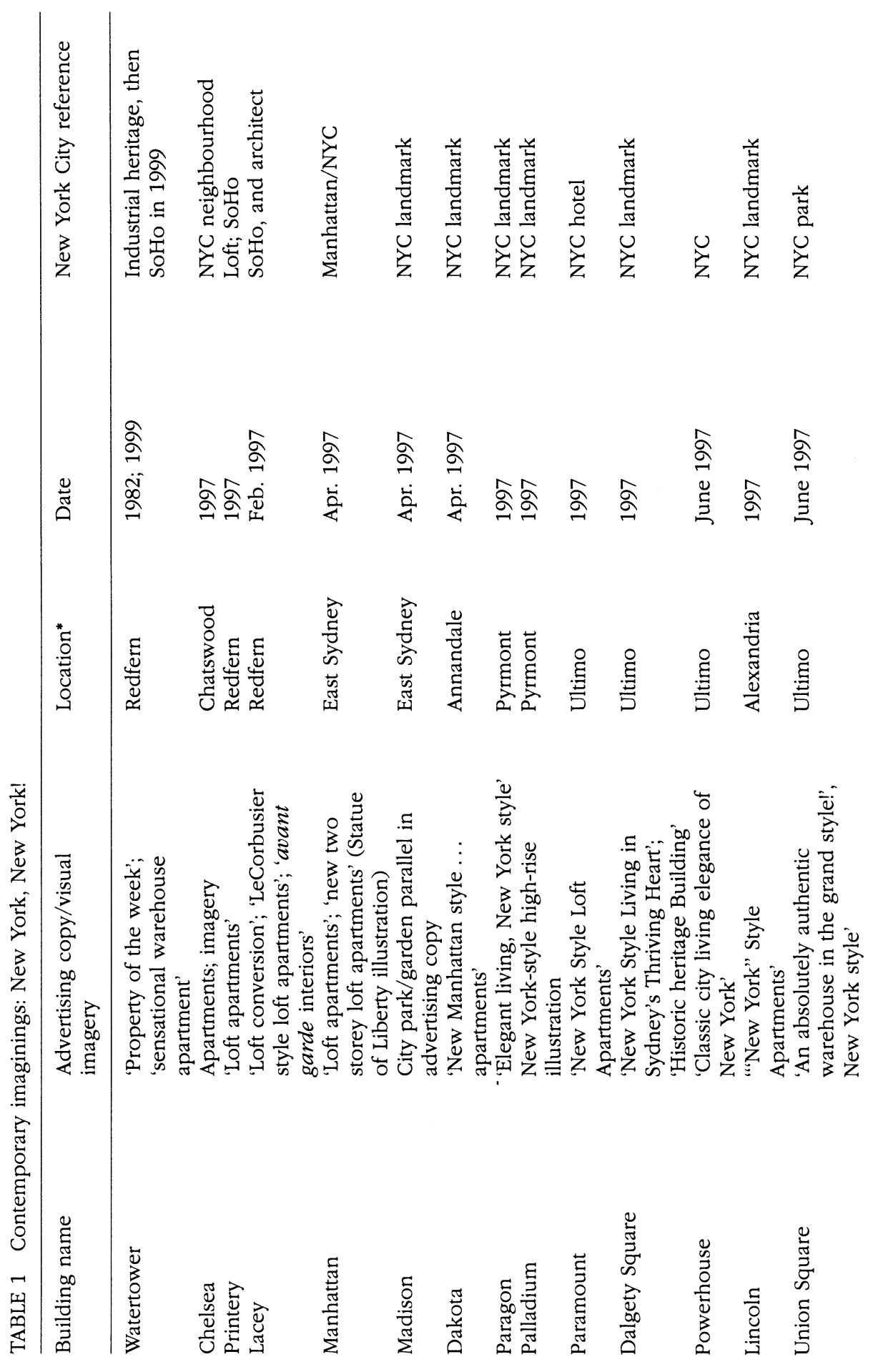




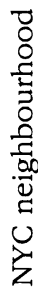

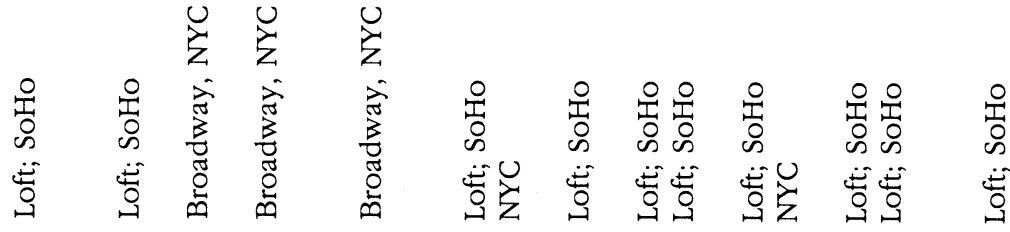

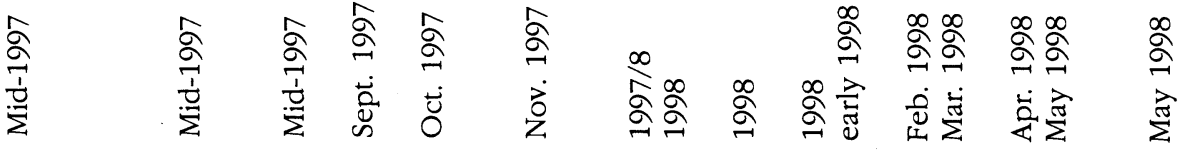

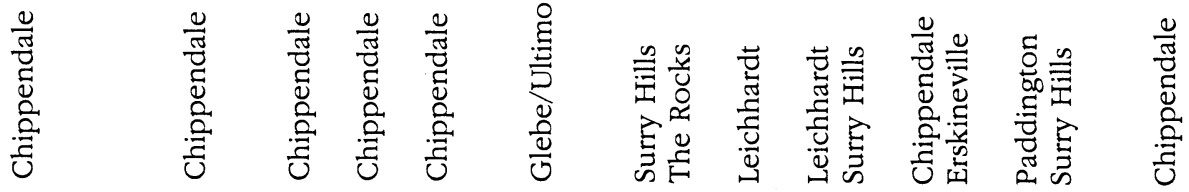

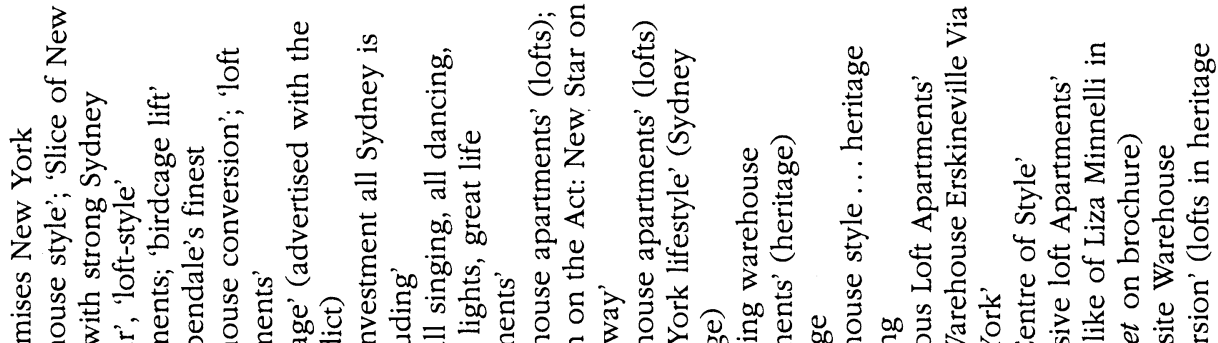

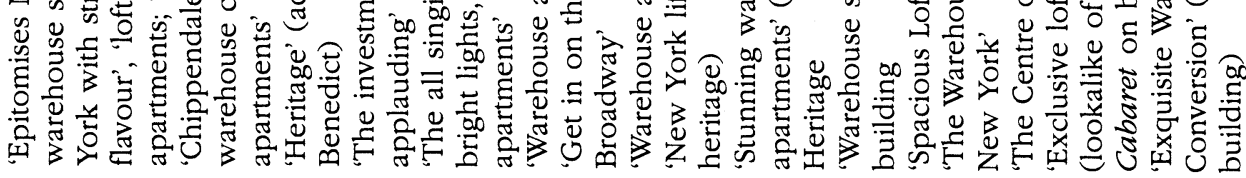

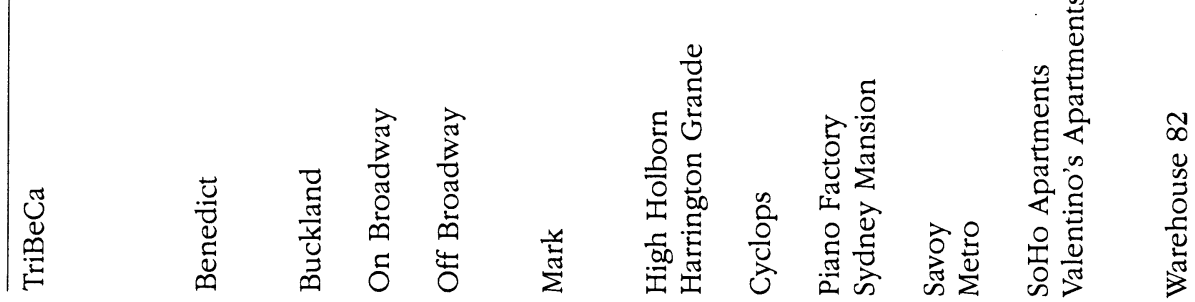




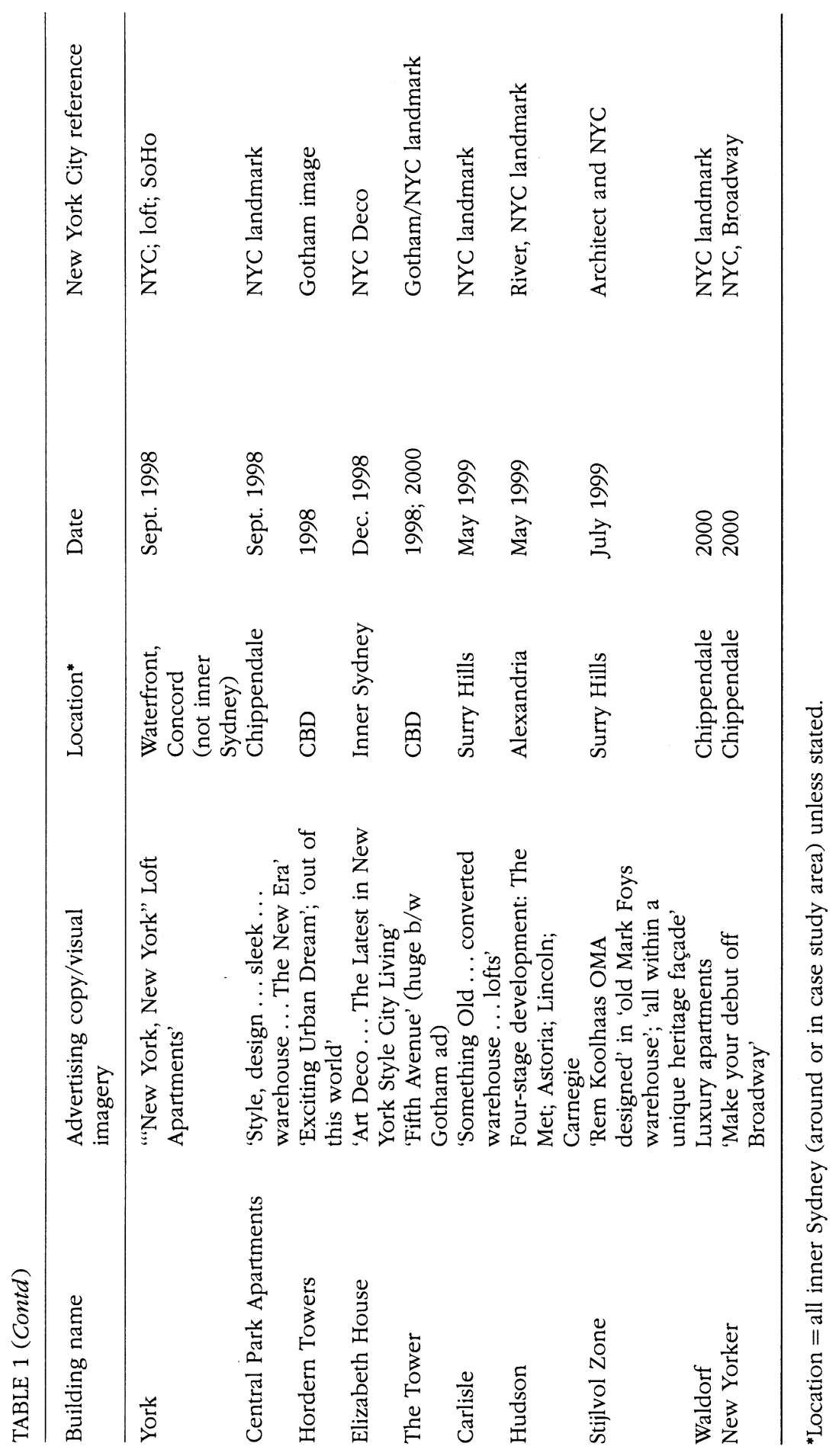


development: 'TriBeCa ...takes its name from a fashionable area in lower Manhattan, New York. ${ }^{86}$

Suddenly the theatre district of Manhattan became the theme for anything near Sydney's Broadway, which is a main thoroughfare to the CBD (and bears no resemblance to a theatre district). The $\mathrm{Mark}^{87}$ was advertised with: 'Get in on the act: new star on Broadway.' In September 1997, On Broadway ${ }^{88}$ had its 'Grand Opening: The Investment all Sydney is applauding ... a choice of superb units and lofts at a price that's a steal on any other show in town ... at the heart of the city's restaurant and entertainment belt.' The promotion could not be more explicit. Seizing the opportunity, the promoters of Off Broadway, ${ }^{89}$ in adjacent Chippendale, produced a glossy brochure with the caption: 'The all singing, all dancing, bright lights, great life apartments'. Then, a full-page advertisement for York apartments ('New Release ... A new YORK Apartment) appeared in what seemed to be a laughable parody of the lyric made famous by that New York icon, Frank Sinatra:

Start spreading the news ... I'm leaving today ... I'll make a brand new start ... If I can make it there, I'll make it anywhere! ... I want to be a part of it ... It's up to you, new YORK, new YORK'.90

Reaching a new level of competitive absurdity, the Metro ${ }^{91}$ in Erskineville, just south of Redfern, offered everything. It was advertised as a 'warehouse conversion apartment [building, with the] best of old world architecture and space with the ultimate in today's conveniences ... cosmopolitan ... video intercom ... security parking'. This complete lifestyle package was advertised under the banner 'Metro-The Warehouse Erskineville Via New York', which blended location(s) with industrial chic, all under the watchful eye of surveillance technologies.

The Manhattan/New York nomenclature continued with SoHo ${ }^{92}$ Apartments, 'The Centre of Style', and the Central Park Apartments. ${ }^{93}$ But the most spectacular and exclusive Manhattan statement was the advertisement for The Tower, ${ }^{94}$ in the commercial heart of the CBD. 'The city's most exclusive residential offering' featured a long, narrow, full-length broadsheet advertisement. The image was a distinctly Gotham City caricature of Manhattan. Later advertisements (SMH, January 1999) evoked 'The vibrancy and pulse of a Manhattan lifestyle', and the same Gotham City image then appeared in atmospheric blue ink, with the words 'The Tower Sydney ... 5th Avenue Residences' (SMH, February 1999).

\section{Cultures of loft consumption}

By the end of the 1990s, loft living had become a well-entrenched housing option for Sydneysiders, ${ }^{95}$ particularly for those with the financial power to put economic necessity at a distance. ${ }^{96}$ Research interviews carried out in 2001 provided personal accounts of loft lifestyles. For one new loft resident,

Basically the apartment made my mind up ... I was searching in the inner city, and when I saw this, I just chose ... this apartment. Not price related, it was a little more over-priced than other places but ... this building is amazing! ${ }^{97}$ 
Although warehouse occupations had saved some buildings from demolition, the sheer number of apartment developments meant that loft living had to move beyond reliance on a supply of historic buildings and the displacement of their low-rent residents. With a well-entrenched cultural capital of industrial chic, the promotional discourse easily replaced the word 'warehouse' with 'loft', and the associated lifestyles grabbed the attention of the popular media. 'Never mind the unit - it's a lifestyle, darling'98 ensured the burial of the old notion of the tired old 'home unit'. The new housing form - the lifestyle apartment - was fast becoming a 'must have' for some, as one loft resident remarked: '[This is] a brand new building. [When] this came up and we were like 'get in' [to the latest trend]. ${ }^{99}$

Sydney's loft living had evolved to a point where references to warehouse heritage was no longer required. However, as detailed earlier, a mandatory accessory of loft living - highlighted throughout the marketing rhetoric - was the inclusion of fortressing technologies. One resident, reflecting on the issue of security, remarked:

It's a great area [but] it has its problems with security, there's no question about that, but once you know what to be careful [of] ... I mean there are certain things you can do to prevent danger ... certain things you can control. ${ }^{100}$

For this loft resident, the capacity to 'control' elements of danger, through care and prevention, combined well with location. Along with the issue of security, the themes of convenient access to the city and public transport were also well rehearsed during research interviews. ${ }^{101}$ Another resident noted an extra dimension to the advantages of location:

I like [it here] because it sits on the crossroads of the major roads ... I spend most weekends away ... and you can hit all the major expressways [easily/quickly]. ${ }^{102}$

When not escaping the city, loft dwellers know that their vehicles are securely locked away, below their apartments, and are (usually) accessible via elevator or stairwell, linked directly to the basement parking lot. Loft lifestyles can proceed unhindered by events outside. As one loft resident remarked:

some people have said that it's quite a bad area ... for me, no problems at all, even if it's two minutes from 'The Bronx' [Redfern]. ${ }^{103}$

Within Sydney's SoHo Syndrome, the physical and metaphorical removal from the realities of the street provides refuge from the presence of danger. ${ }^{104}$ Any engagement with the local area is by choice, not necessity. The attributes of fortressed urbanity are part of this version of cosmopolitanism. In one area, stigmatized by the presence of the Aboriginal community of 'Redfern', ${ }^{105}$ promotion of property fortressing has assisted in the establishment of beachhead developments, and these have wedged open spaces for the colonization of an otherwise 'no-go zone' by highly secured apartment blocks (Figure 3). ${ }^{106}$ Although danger is now largely avoidable for loft dwellers, it can serve another purpose, as observed by a resident of one of the early loft conversions:

When [we] first moved in here we had dinner over the other side... and we walked [back] down through ... ['Redfern']. I knew there was a degree of risk attached ... I've lived in a number of cities in the 


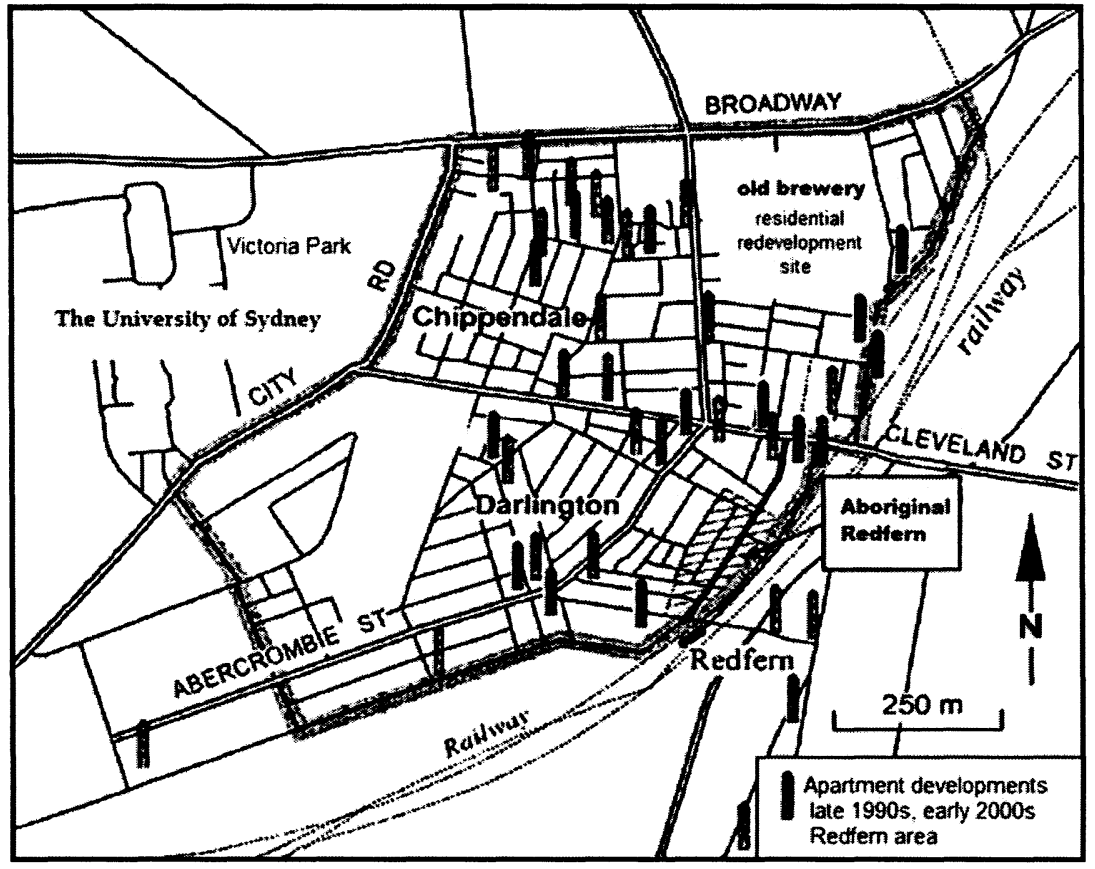

FIGURE 3 Apartment developments of the late 1990s (Redfern area)

world that would only be considered highly dangerous ... I was pretty alert and astute to what was going on. But I did it as an exposure to myself, and particularly, ... because [my partner] really wanted to. ${ }^{107}$

This resident had chosen to be a tour guide in the city's theatre of danger, where danger is entertainment and, perhaps, an education. Although not a pursuit that appeals to everybody, a real-estate agent mentioned that the presence of 'the ghetto' added 'culture and colour' to the area, giving it a special-interest focal point. ${ }^{108}$ For some, an edge of danger is part of the attraction of city living; ${ }^{109}$ it added a little extra to the smorgasbord of cosmopolitan offerings.

Safe within their loft apartments, and away from the potentially dangerous and sometimes thrilling local area, new loft residents can relax, and disengage. According to Simmel:

The essence of the blase attitude is an indifference toward the distinctions between things.... What appears ... as dissociation is in reality ... one of the elementary forms of socialization. ${ }^{110}$

For those with the economic capacity to choose to live in a city apartment, loft living offers new cultural formations that resemble the kinds of urbanism that can be imagined to exist in any urbane city where the hum and throb of the street exists outside, and below the sanctuary of the apartment. Such urbanisms have captured the attention of Sydney's property consumers, be they new residents or savvy investors. One resident summarized the attraction of loft living: 
[The apartment had] space and... good light, and the area appealed to us... its urban, recycled warehouses ... that sort of thing ... easy walking distance or easy transport options. ... [The apartment] had what we wanted. ${ }^{111}$

The commercially manufactured urbanisms associated with apartment living in Sydney come with a range of socialized capacities. These include the ability to engage in safe, urbane and convenient lifestyles that can deny, be indifferent (or blasé) to, or utilize aspects of the local, its history and its pathology, for entertainment or consumption purposes. These sorts of urbanisms are now embedded; they are a part of Sydney's SoHo Syndrome. The promotions of these ways of living, in the increasingly exclusive and exclusionary cosmopolitan metropolis, continue to this day.

\section{Conclusions}

City imaginings are increasingly detached from urban reality ... promotional rhetoric ... conceal, and partly effect, gross economic and political inequalities. ${ }^{112}$

Following other contemporary studies of urban transformation in geography, this essay has teased out local experiences that are linked to broader political economies and identity formations, by explicitly detailing processes of urban transformations through the production as well as the consumption of housing. It has detailed aspects of the reimaging of the city of Sydney through the advent of loft living. It has documented the development of a new form of built environment that appears to mimic the New York version. The marketing rhetoric behind the promotions of Sydney's loft living produced certain kinds of urbanism, which were discursively embedded as part of Sydney's SoHo Syndrome. But, as Podmore identified with other cities, SoHo Syndromes are more than mimicry. Sydney's version is a package of Manhattan referents and place-based cultural encodings, formed as part of a wider process of cosmopolitanism produced, as well as consumed in the new urbane city.

In this essay, I have sketched a trajectory - the processes behind a cultural shift - to apartment living in Sydney. One purpose of this essay was to introduce a mostly forgotten, or only partially remembered, history that has contributed to a much wider appreciation of 'industrial chic' which was, I have argued, pivotal to a move towards apartment appreciation. I traced the progression from warehouse to loft living, and detailed how earlier conversions of industrial buildings, and the occasional façade and memories that remain, provided a stepping stone for the fully commodified and mass produced versions of loft living, which then traded on the imaginings of elsewhere.

This original 'lofting' of parts of Sydney, through informal/illegal occupations of cheap, somewhat bohemian rental alternatives in the inner city, depended on a variety of economic and other contingencies, which gradually faded with shifts in local and global economic forces. These earlier warehouse lifestyles, and traces of them that remain, may have provided appreciation for industrial chic but they remain largely unacknowledged, rendered unnecessary in the marketing of loft living. Unlike the New York scenario, ${ }^{113}$ the Sydney 'scene' remained largely 'illegal', underground and mostly 
unrecorded. The result was the lack of a formalized 'historic compromise' between culture and capital in the urban core of Sydney, as Zukin ${ }^{114}$ identified in New York. Without this compromise, which acknowledged a phase of artist-driven preservation and improvement of formerly run-down city spaces in Manhattan's SoHo, Sydney's warehouse occupations remain largely hidden within the city's cultural fabric. Only when memories are jogged, and alternative sources mined for evidence, do glimpses of this 'lost' history appear. This absence provided a clean slate, for a rewriting of Sydney's urban script that was cleverly inscribed onto the emergent housing landscape.

The advent of loft landscapes in Sydney, in the late 1990s, is the embodiment of global and local, economic, cultural and political processes that have provided property developers with large-scale opportunities. At the same time, they created new and exciting, but also increasingly exclusionary forms of urbanisms, or ways of living in the city. Sydney's own histories, and the 'cities of differences', ${ }^{115}$ which are part of those histories and part of Sydney's contemporary inner-urban residential landscape, find no expression except as consumable offerings in the cosmopolitan metropolis. The production of loft living in Sydney has reoriented the style and function of the city in spectacular ways. Nonetheless, the specificities of inner Sydney as a locale, as well as the complexity of issues of identity that are promoted, and not promoted, bypassed or consumed as part of a city's cosmopolitan urbanism, remain ever-present within Sydney's SoHo Syndrome.

\section{Acknowledgements}

The former School of Geography, The University of New South Wales, provided a small research grant for the 2001 interviews. Thanks to Jack Aisbett, Elpiniki Joseph and Bryony Wood for research assistance. Thanks also to Natascha Klocker and AnneLouise Semple for comments.

\section{Notes}

${ }^{1} \mathrm{~J}$. Collins, Architecture of excess: cultural life in the Information Age (New York, Routledge, 1995), p. 93.

2 Apartments in Australia are 'home units' in high-rise buildings, which are similar to condominiums in North America, and can be owner-occupied or rented by a tenant from a landlord. For the purposes of this essay, 'apartments' refers to lofts/loft apartments.

${ }^{3}$ S. Watson, 'Gilding the smokestacks: the new symbolic representations of deindustrialised regions', Environment and planning D: society and place 9 (1991), pp. 59-70; D.Crilley, 'Architecture as advertising: constructing the image of redevelopment', in G. Kearns and C. Philo, eds, Selling places: the city as cultural capital, past and present (Oxford, Pergamon Press, 1993), p. 231; P. Jackson, 'Manufacturing meanings: culture, capital and urban change', in A. Rogers and S. Vertovec, eds, The urban context: ethnicity, social networks and situational analysis (Oxford, Berg, 1995), pp. 165-88. 
${ }^{4}$ P. Redfern, 'A new look at gentrification: 1, Gentrification and domestic technologies', Environment and planning A 29 (1997), pp. 1275-96.

${ }^{5}$ House prices in inner Sydney increased by 19\% between 1993 and 1996 (compared to 9\% and $8 \%$ in middle and outer city zones), and units/apartments increased by $24 \%$ over the same period (compared to $3 \%$ and $4 \%$ increases for middle and outer city zones): M.T. Daly, 'Reshaping Sydney: the inner city revival', Urban policy and research 16 (1998), p. 60. According to the Reserve Bank of Australia (2002), 'house prices increased at a rate of over 9 per cent per annum nationally over the past five years, and by 17 per cent over the past year'.

${ }^{6}$ S. Zukin, Loft living: culture and capital in urban change (London, Johns Hopkins Press, 1982).

7 Watson, 'Smokestacks'; M. Goodwin, 'The city as commodity: the contested spaces of urban development', in Kearns and Philo, Selling places; P.L. Knox, ed., The restless urban landscape (Upper Saddle River, NJ, Prentice Hall, 1993); J.R. Short, L.M. Benton, W.B. Luce and J. Walton, 'Reconstructing the image of an industrial city', Annals, Association of American Geographers 83 (1993), pp. 207-24. P. Hubbard, 'Urban design and city regeneration: social representations of entrepreneurial landscapes', Urban studies 33, (1996), pp. 1441-62; M. Keith and S. Pile, 'Imaging the city', Environment and planning A 28 (1996), pp. 381-87; J. Goss, 'Representing and re-presenting the contemporary city, progress report', Urban geography 18 (1997), pp. 180-88.

$8 \mathrm{~N}$. Thrift and D. Walling, 'Geography in the United Kingdom 1996-2000', Geographical journal 166 (2000), pp. 96-124, for review.

9 For Sydney, see Post occupancy survey of new residents in Ultimo Pyrmont (Sydney, Department of Urban Affairs and Planning, 1996).

10 S. Zukin, 'Gentrification: culture and capital in the urban core', Annual Review of sociology 13 (1986), p. 129.

11 Crilley, 'Architecture as advertising'; P.W. Daniels, Service industries in the world economy (Oxford, Blackwell, 1993); M. Pryke, 'Urbanizing capitals: towards an integration of time, space and economic calculation', in S. Corbridge, N. Thrift and R. Martin, eds, Money, power and space (Oxford, Blackwell, 1994); Collins, Architecture of excess); J. Eade, ed., Living in the global city (London, Routledge, 1997); Clark, 'World urban development: process and patterns at the end of the twentieth century', Geography 85 (2000), p.

12 D. Ley, 'Transnational spaces and everyday lives', Transactions of the Institute of British Geographers 29 (2004), pp. 151-64.

13 These draw on G. Simmel, 'The metropolis and mental life', in P. Kasinitz, ed., Metropolis: centre and symbol of our times (New York, New York University Press, 1995); L. Wirth, 'Urbanism as a way of life', in Kasinitz, Metropolis; W. Benjamin, 'Paris: capital of the nineteenth century', in Kasinitz, Metropolis; See also D. Harvey, Society, the city and the space-economy of urbanism, (Washington, DC, Association of American Geographers Resource Paper, 1972).

${ }^{14}$ D. Clark, 'World urban development: processes and patterns at the end of the twentieth century', Geography 85 (2000), p. 17.

15 After Ley, 'Transnational spaces'.

${ }^{16}$ M. Davis, 'Fortress Los Angeles: the militarization of urban space', in Kasinitz, Metropolis, p. 2.

${ }^{17}$ M. Dear and S. Flusty, 'Postmodern Urbanism', Annals of the Association of American Geographers 88 (1998), pp. 50-72; M. Dear, The postmodern urban condition (Oxford, Blackwell, 2000). 
18 Which, as revealed in Fig. 3, includes conflations of loft living imaginaries with a host of Manhattan/New York attributes, including neighbourhoods and buildings.

19 P. Bourdieu, 'The forms of capital', in J. Richardson, ed., Handbook of Theory and Research for the Sociology of Education (New York, Greenwood Press, 1986), pp. 241-58.

$20 \mathrm{~J}$. Podmore, '(Re)Reading the loft living habitus in Montreal's inner city', International journal of urban and regional research 22 (1998), pp. 283-302.

${ }^{21}$ C. McGuigan, S. Katz, P. King and M. Miller, 'The SoHo syndrome: artists are revitalizing city neighbourhoods', Newsweek (22 Sept. 1986), pp. 80-81, cited in Podmore, '(Re)Reading the loft living habitus'.

22 Ibid., p. 284.

${ }^{23}$ Ibid.

${ }^{24}$ D. Cole, 'Artists and urban redevelopment', Geographical review 77 (1987), pp. 391-407; Jackson 'Manufacturing meanings'; A. Bowman, 'Reshaping the city', in J. Walter, H. Hinsley and P.S. Pearritt, Changing cities: reflections on Britain and Australia (London, Sir Robert Menzies Institute of Australian Studies, University of London, 1995), p. 138.

${ }^{25}$ Simmel, 'Metropolis'.

26 W.S. Shaw, 'Ways of whiteness: negotiating settlement agendas in (post)colonial inner Sydney', PhD thesis, Department of Geography, University of Melbourne, 2001; http:// eprints.unimelb.edu.au/archive/00000242/01/Shaw.pdf

${ }^{27}$ Simmel referred to this protection process as the production of a 'protective organ', in 'Metropolis' p. 31.

${ }^{28}$ Crilley, 'Architecture as advertising'.

29 C. Simpson, SoHo: the artist and the city (Chicago, University of Chicago Press, 1981); Zukin, 'Loft living'.

${ }^{30}$ Cf. H. Lefebvre, Everyday life in the modern world (New York, Harper \& Row, 1971); J. Eyles, 'The geography of everyday life', in D. Gregory and R. Walford, eds, Horizons in buman geography (Basingstoke, Macmillan, 1989). For Sydney see G. Waitt and P.M. McGuirk, 'Marking time: tourism and heritage representation at Millers Point, Sydney', Australian geographer 27 (1996).

31 A prescriptive form of urbanism, 'new urbanism', has also entered the discourses of planning and architecture. This 'outcome-based view of planning based on a vision of a compact, heterogeneous city' (S. Fainstein, 'New directions in planning theory', Urban affairs review 35 (2000), p. 451) is distinct from the kinds of urbanism that are attended to in the recent surge of interest in urbanism in geography.

32 Cited in Ley, 'Transnational spaces', p. 162.

33 W.S. Shaw, 'Ways of whiteness: Harlemising Sydney's Aboriginal Redfern', Australian geographical studies 38 (2000), pp. 291-305. As with the 'A' in Aboriginal, the ' $\mathrm{I}$ ' in Indigenous is capitalized in accordance with Australian Aboriginal protocols.

${ }^{34}$ M.C. Boyer, The city of collective memory: its bistorical imagery and architectural entertainments (Cambridge, MA, MIT Press, 1998).

35 P. Jackson, 'Manufacturing meanings', p. 181.

36 'Manhattanism ... [is] an unformulated theory... program [is] to exist in a world totally fabricated by man $[s i c]$, ie to live inside fantasy ... Manhattanism ... [is] an explicit doctrine that can transcend the island of its origins to claim its place among contemporary urbanisms': R. Koolhaas, Delirious New York: a retroactive manifesto for Manbattan, New York (Oxford, Oxford University Press, 1978), p. 7.

37 M. Crang, 'Qualitative methods: the new orthodoxy?', Progress in buman geography 26 (2002), pp. 647-55. 
${ }^{38}$ E.g. data was gathered from the Newtown Times and several street magazines, including the now defunct On the street; website, http://mdcm.students.arts.unsw.edu.au/click/alpha house/preview.html and CD-ROM; liner notes from Freaky loops, CD, Sydney: Cryogenesis/ 2SER/MDS (1998); 'The sultans of spin', http://smh.com.au/articles/2002/06/23/102386452 7278.html?oneclick $=$ true

39 Quantitative data was used to establish statistical trends about population increases and demographic characteristics (Australian Bureau of Statistics reports). Property price changes for the inner city of Sydney (1997-2001) were established by tabling prices, published weekly in Sydney's main broadsheet newspaper, the Sydney Morning Herald. These were checked against the Real Estate Institute's reports on trends.

${ }^{40}$ An archive of advertisements in the Sydney Morning Herald (newspaper and internet-based sources) for Sydney's loft apartments was started in 1997, and contributions continue to this day. I used content and discourse analysis techniques on documents and texts.

${ }^{41}$ Rather than use a large-scale survey of a statistically representative area, I used a combination of non-directional interviews/informal surveys (with residents of inner Sydney who volunteered through a process of targeting every third household within the specifically affected area of Darlington, Chippendale and Redfern in inner Sydney), and collections of media-generated texts, newspaper articles and advertisements for 'lofts', and any written materials generated by events such as council meetings about a proposed development (council documentation, press releases, newspaper articles).

42 In 2001, every third apartment in newly occupied loft apartment buildings in the Darlington, Chippendale and Redfern area, as well as several buildings in the Central Business District of Sydney (most were under construction therefore few were as yet residentially occupied), were canvassed for interview participants. The interviews provided personal stories about loft living in Sydney - the 30 interviews do not constitute a statistically representative sample. Quotes, and some content analysis of the interview material, provided the data for a paper titled 'GISc and cultural applications: social polarization and spatial co-incidence' by B.G. Lees and W.S. Shaw, presented at the Association of American Geographers annual meeting in Los Angeles in 2002.

43 P. Murphy and S. Watson, Surface City: Sydney at the Millennium (Australia; Pluto Press, 1997) on urban and suburban homosexual spaces in Sydney, and L.N. Costello and S. Hodge, 'Queer/clear/here: destabilising sexualities and spaces', in E. Stratford, ed., Australian Cultural Geographies (Sydney, Meridian, 1999).

44 J. Roseth, 'Residential conversions in Sydney', RAPIJ (May 1981), pp. 76-78.

45 The state of New South Wales.

${ }^{46}$ R. Horvath and B. Engels, 'The residential restructuring of inner Sydney', in I. Burnely and J. Forrest, eds, Living in cities: urbanism and society in metropolitan Australia (Sydney, Allen \& Unwin, 1985), p. 146.

47 S. Coombs, Sex and anarchy: the life and death of the Sydney Push (Australia, Penguin, 1996), p. viii.

48 Zoning regulations in South Sydney and Sydney City Councils changed to enable warehouses and old office blocks to undergo residential conversion, and many industrial/business zonings changed to Zone $2 \mathrm{~b}$, 'medium density residential', and Zone 10 , 'mixed use'.

49 Roseth, 'Residential conversions', p. 77.

50 J. Vipond, K. Castle and R. Cardew, 'Revival in inner areas', Australian planner 35 (1998), pp. 215-22.

51 Ibid., p. 216.

52 Sassen-Koob, 1985; Daly, 'Reshaping Sydney'. 
53 Roseth, 'Residential conversions'.

54 Ibid., p. 77.

55 Ibid.

56 Ibid. (emphasis added).

57 Zukin, 'Loft living'; Podmore, '(Re)Reading the loft living habitus'.

58 Margaret Rapis, a media and communications student at the University of NSW, produced a CD-ROM memento of Alpha House. According to Rapis, Alpha House, 'once a haven for the creative, is one of the wounded prey of the economically rational status quo'. (http:// mdcm.students.arts.unsw.edu.au/click/alpha_house/preview.html). The new 'loft apartment' development has retained the Alpha House name.

59 My personal favourite was the gothic-vampiric occupation and multiple uses of the cavernous Xerox building in the early to mid-1980s; and the Anthony Hordens building hosted an event of epic proportions, which included what was at the time a prestigious lineup of local bands, the night before demolition.

${ }^{60} \mathrm{I}$ lived in the shadow of this building in a terraced house, and was involved in resident activism to save the building from conversion.

61 This building was just down the street from where I had lived, and I followed the process of its transformation long after I had left the area.

62 From discussions with warehouse survivors about (our) personal experiences of the Slaughterhouse' in the mid- to late 1980s and again in the early 1990s, which included reminiscences about the characters and bands that practised and performed there. For a list of Australian bands from that era see http://www.innercitysound.com.au.

63 The property developer was Ivanhoe Pty. Ltd., and the plans to convert Beta House into apartments were sighted at (the former) South Sydney City Councils Planning and Building Department.

${ }^{64}$ Robmet completed the development of 66 apartments in 2001.

${ }^{65}$ From the late 1980 s to 1995 , the Sydney 'rave' scene also used these warehouses. See S. Chan, liner notes, Freaky loops: Cryogenesis/2SER/MDS (1998), and C. Gibson and R. Pagan, 'Rave cultures in Sydney, Australia: mapping youth spaces in media discourses', in M.A. Wright, ed., Dance culture, party politics and beyond (London, Verso, 2000).

${ }^{66}$ http://mdcm.students.arts.unsw.edu.au/click/alpha_house/preview.html

67 Sun Herald (15 Aug. 1982), p. 18.

68 Personal communication, Newtown Times.

69 Research interview, 29 Apr. 1998.

70 Roseth, 'Residential conversions', p. 77.

71 Vipond et al., 'Revival in inner areas'.

72 Sydney Morning Herald (27 Feb. 1999), p. S1.

73 The Statue of Liberty is an icon of New York. Although it is associated with Manhattan, it is not on the island itself. The (silver) human statue reappeared (gold version) in 2003.

74 Jahn, Sydney Morning Herald (3 Feb. 2001), p. 4A.

75 Glebe E Inner Western Weekly (3 Sept. 1997).

76 Not to be confused with the newer Central Park Apartments, in Chippendale (promoted in Sept. 1998).

77 In this section, all quotes about the developments are taken from their promotional materials.

78 This list exemplifies the kinds of advertisement that dominated the discourses for selling Sydney's loft living from 1997 until 2000 (with the exception of the Watertower, which was converted to apartments in 1982). 
79 For discussions see Davis, 'Fortress Los Angeles'; M. Sorkin, ed., Variations on a theme park (New York, Hill \& Wang, 1990); J. Hillier and P. McManus, 'Pull up the drawbridge: fortress mentality in the suburbs', in K. Gibson and S. Watson, eds, Metropolis now (Sydney, Pluto Press, 1994); E. McKenzie, 'Trouble in Privatopia', Progressive 57 (1993), p. 30; G. Morgan, 'Acts of enclosure: crime and defensible space in contemporary cities', in Gibson and Watson, Metropolis Now; E. Soja, 'Heterotopologies: a remembrance of other spaces in Citadel LA', Strategies 3 (1990), pp. 6-30.

80 Paddington is the benchmark suburb for Sydney's gentrification.

81 Sydney Morning Herald (Apr. 1997).

82 Ibid.

83 Ibid.

${ }^{84}$ Ibid. (June 1997).

85 Ibid.

86 Glebe E Inner Western Weekly (3 Sept. 1997).

87 Sydney Morning Herald, (Nov. 1997).

88 Ibid. (Sept. 1997).

89 Ibid.

90 Inner Western Courier (7 Sept. 1998); capitalization taken directly from advertisement.

91 Real Estate Agents L.J. Hooker letter-box drop, (Mar. 1998)

92 Sydney Morning Herald (11 Apr. 1998).

93 Inner Western Suburbs Courier (17 Sept. 1998).

94 Sydney Morning Herald (Mar. 1998).

95 In Australia, the number of people living in high-rise units rose from approximately 129000 in 1981 to around 334000 in 2001, with more than half (68\%) of all high-rise residents living in New South Wales: Australian Bureau of Statistics, Australia now, 2: Australian social trends, highrise living report (15 June 2004). Between 1994 and 1999, 12970 Development Applications (DAs) for 'residential projects' (apartment buildings) were approved for construction in the City of Sydney Local Government Area, with 7330 completions. Between 1999 and 2004, 6329 DAs were approved, and there were 7257 completions (City Residential Monitor, City of Sydney, 2000, 17, p. 3; 2004, 35, p. 3).

96 P. Bourdieu, Distinction: a social critique of the judgement of taste (London, Routledge, 1984).

97 Research interview, Nov. 2001.

98 Other examples include: 'Fabulous homebodies: marketing the urban dream', Sydney Morning Herald (19 June 1999); 'Step up to life in the Style Zone', Sydney Morning Herald (17 July 1999); ibid. (20 Apr. 2000); 'Moveable modernism: a Sydney design duo creates a buzz from New York', Sydney Morning Herald (20-26 Apr. 2000); and the more recent warning of loss of local amenity and culture in 'Too much sacrificed at The Cross', Sydney Morning Herald (27 May 2003).

99 Research interview, Nov. 2001.

100 Ibid.

101 These locational themes dominated the research narratives: Lees and Shaw, 'GISc and cultural applications'.

102 Research interview, Nov. 2001.

103 Ibid. 'The Bronx' is a reference to the infamous Aboriginal community in Redfern. See Shaw, 'Ways of whiteness'. 
104 . For most of the residents of luxury apartments interviewed in 2001, local-scale issues were subordinate to the broader economic/geographical issues, such as cost of property versus convenience/access to the CBD.

105 'Redfern' is also known as 'Aboriginal Redfern', 'The Block' or 'Eveleigh Street'.

106 Shaw, 'Harlemising Redfern'.

107 Research interview, 4 Feb. 1998.

108 Research interview, 27 July 1998.

109 N. Smith, The new urban frontier: gentrification and the revanchist city (London, Routledge, 1996).

110 Simmel, 'Metropolis', pp. 35-36.

111 Research interview, Nov. 2001.

112 J. Goss, 'Representing and re-presenting the contemporary city', p. 181.

113 Jackson, 'Manufacturing meanings'.

114 Zukin, 'Loft living'.

115 R. Fincher and J.M. Jacobs, eds, Cities of difference (New York, Guilford Press, 1998). 